引用格式:苏腾, 黄河清, 周园园. 黄河宁蒙河段水文-水温过程和河道形态变化对凌汛的影响 [J]. 资源科学, 2016,38(5): 948955. [Su T, Huang H Q, Zhou Y Y. Effect of hydrological processes, water temperature and river channel geometry changes on ice floods in the Ningxia-Inner Mongolia Reach of the Yellow River[J]. Resources Science, 2016, 38 (5) : 948-955]. DOI: 10.18402/ resci.2016.05.14

\title{
黄河宁蒙河段水文-水温过程和河道形态变化 对凌汛的影响
}

\author{
苏 腾 $^{1,2}$, 黄河清 ${ }^{1}$, 周园园 ${ }^{1}$ \\ (1.中国科学院地理科学与资源研究所陆地水循环与地表过程重点实验室, 北京 100101 ; \\ 2. 中国科学院大学, 北京 100049)
}

\begin{abstract}
摘 要: 黄河宁蒙河段的水文和水温过程近几十年来发生了显著变化,迫切需要评估这一变化对河道形态、凌 汛的影响及其可能的致灾效应。利用同水位河道过水断面形态参数分析方法,选取宁蒙河段稳定封冻区域(石嘴 山一头道拐) 的石觜山、磴口、巴彦高勒、三湖河口和头道拐 5 个主要水文站, 根据 2008-2013 年凌汛前实测断面资 料,计算相应年份 5 个水文站同水位下的河道断面面积、平均水深和深泓点高程。结果表明,宁蒙河段近年来凌汛 期的径流量和水温呈现逐渐增大的趋势, 下泄流量过程有助于减少凌灾发生的几率; 各水文站凌汛前的断面面积 和平均水深等断面形态参数呈逐年增大的趋势, 深泓点高程不断降低。河道过水断面形态的这种变化增大了凌汛 期河道的过流能力, 有助于缓解开河期可能出现的凌汛灾情。
\end{abstract}

关键词: 黄河宁蒙河段; 凌汛; 河道形态; 水文过程; 水温过程

DOI: $10.18402 /$ resci.2016.05.14

\section{1 引言}

凌汛是由于下游河道结冰或冰凌积成的冰坝 阻塞河道, 使河水不能流畅下泄而造成水位上涨的 现象 ${ }^{[1,2]}$ 。中国北方的大河,如黄河、黑龙江、松花江 等,许多河段水流由于向北流动,在冬季的封河期 和春季的开河期均容易出现凌汗 ${ }^{[3,4]}$ 。宁蒙河段是 黄河流域凌汛最为严重的河段之一, 历史上曾发生 过多次凌汛灾害 ${ }^{[5]}$ 。冰凌的形成主要是受到水文条 件(流量、水位、流速等)、热力条件(温度)、河道形 态以及人为因素 (水库等) 的影响 ${ }^{[6,7]}$ 。历史上, 宁蒙 河段 11 月下旬开始流凌, 12 月上旬至次年 3 月下旬 为封冻期,封冻时间为 120 天左右 ${ }^{[8]}$ 。但是自 20 世 纪90年代以来, 宁蒙河段的凌汛特征发生了明显的 改变 ${ }^{[9]}$, 流凌和封河日期推迟, 开河日期提前, 稳定
封冻天数减少, 最大槽蓄水量明显增加, 冰坝出现 次数减少, 开河期冰盖多为就地消融, 冰盖断裂出 现次数明显减少 ${ }^{[10]}$ 。

宁蒙河段凌汛特征的变化与上游水库的修建 和调度关系密切 ${ }^{[1,12]}$ 。水库控制下泄流量过程, 从 而对凌汛产生影响,理想下泄过程的特点为: (1)封 河前夕适当增大流速, 避免浮冰滞于河道, 推迟封 河日期; (2)封冻过程 (河段首封点出现至河段全线 封河)中及时减小流量,防止“立封”和产生冰塞; (3) 封河期适当增大流速,减小河槽蓄水量, 削减开河 期的凌峰流量 ${ }^{[6]}$ 。水库的另一作用体现在对水温的 影响,水库发电泄流的热力作用使得宁蒙河段水温 升高, 冰层变薄 ${ }^{[13]}$ 。研究表明,水库通过调控水文过 程和热力条件对黄河宁蒙河段凌汛起到了一定的

收稿日期: 2016-01-10; 修订日期: 2016-04-05

基金项目: 国家国际科技合作专项(2013DFA91700); 宁夏水利厅委托项目;国家自然科学基金面上项目(51179181)。

作者简介: 苏腾, 男, 山东泰安人,博士生, 主要从事河流地貌研究。E-mail : sut.12s@igsnrr.ac.cn

通讯作者: 黄河清,E-mail : huanghq@igsnrr.ac.cn

http://www.resci.cn 
控制作用。但是, 水库的建设与调度也对河道断面 形态产生影响。特别是河道断面面积与汛期水沙 过程密切相关。水库运行后, 库下河道的来水来沙 及洪水过程发生改变,会引起河道形态的变化 ${ }^{[14,15]}$ 。 宁蒙河段的冲淤演变过程和方式十分复杂,河道形 态的变化将直接影响到凌汛期河道的过流能力、槽 蓄水量和开河水位等 ${ }^{[16]}$ 。然而河道形态变化对宁蒙 河段凌汛的影响尚未得到深人的分析。因此,深人 分析宁蒙河段近年来河道形态的变化,揭示其变化 规律是目前面临的关键科学问题。本文根据宁蒙 河段稳定封冻区域 5 个主要水文站的实测水文和河 道过水断面资料,分析凌汛过程和河道过水断面形 态的变化趋势, 为更加有效的治理凌灾提供科技 支撑。

\section{2 研究区概况}

宁蒙河段位于黄河上游的末端, 是黄河最靠北 的河段(图 1)。该河段上起宁夏中卫市,下讫内蒙 古托克托县, 全长 $1217 \mathrm{~km}$, 其中宁夏河段长 $397 \mathrm{~km}$, 内蒙古河段长约 $820 \mathrm{~km}^{[17]}$ 。河段主要支流有“十大 孔兑” 等,夏季汛期暴雨产生的山洪携带大量泥沙 经这些支流注人黄河, 导致主槽摆动, 河床淤积抬

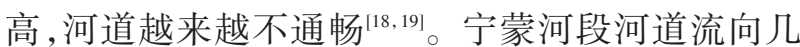
经转变: 自宁夏中卫市南长滩至内蒙古磴口县, 河 道大致自西南向东北流动; 自磴口县至呼和浩特市 喇嘛湾, 大致自西北向东南流动; 喇嘛湾以下, 河道 基本为自北向南流动。受大陆性季风气候控制, 宁 蒙河段所在区域冬季寒冷干燥, 平均气温在 $0{ }^{\circ} \mathrm{C}$ 以 下的时间可持续 $4 \sim 5$ 个月, 极端气温达 $-39^{\circ} \mathrm{C}^{[20]}$ 。每 年 12 月到翌年 3 月,河面结冰。由于纬度差异引起 气温差异,河段下游的封河时间早于上游,开河时 间晚于上游,使得凌汛期容易出现冰塞、冰坝等特 殊凌情,严重的将导致凌灾的发生 ${ }^{[21]}$ 。

宁蒙河段是黄河上游重要的冲积河段,由峡谷 段、库区段和平原段三部分组成。其中从中卫市南 长滩至中宁县杳园为峡谷河段,坡陡流急, 不常封 冻。由于水库对流量的调节和对水温的影响, 青铜 峡库区段也为不常封冻的河段 ${ }^{[10]}$ 。自宁夏石嘴山至 内蒙古头道拐河段,河道较上游部分宽浅,比降缓, 该区间位置更加靠北, 温度也更低, 为稳定封冻河 段。因此,石嘴山至头道拐区间是本文重点研究的
河段。

\section{3 数据来源与研究方法}

石嘴山站、磴口站、巴彦高勒站、三湖河口站、 头道拐站是黄河宁蒙河段稳定封冻区域内具有长 期观测记录的 5 个水文站。该稳定封冻河段河型复 杂, 其中磴口站处于顺直河段,巴彦高勒站处于辫 状河段, 三湖河口站处于弯曲河段,头道拐站处于 顺直河段。这 5 个水文站河道断面的变化可以揭示 宁蒙河段稳定封冻区域不同河型段的河道变化特 征,因此本文以这 5 个水文站的河道断面形态作为 主要研究对象。这 5 个水文站通常每年测量两次河 道过水断面形态, 其中最晚一次的测量时间为 9-11 月,所测断面数据能反映凌汛期前的河道状况。因 此,本研究选取 5 个水文站 2008-2013 年各年最晚 一次的河道断面数据进行分析。上述数据由黄河 水利委员会测得并记录于黄河流域水文资料汇编 中 ${ }^{[2]}$ 。

本研究采用同水位断面分析方法计算河道断 面形态的主要要素 ${ }^{[23]}$ 。由于各站各年凌汛期前所测 断面的水位不同,选取各站 2008-2013 年期间的最 低水位作为同水位,计算各断面在该同水位以下部 分的断面形态要素,对比河道断面形态的变化。其 中,河道断面面积由通过对同水位以下部分的断面 进行积分计算所得,水面宽为同水位线与断面线左 右交点间的水平距离,平均水深为断面面积除以水 面宽。

\section{4 分析与结果}

\section{1 凌汛期水文-水温过程变化特征}

\subsection{1 青铜峡水库凌汛期下泄水量过程}

青铜峡水库位于宁夏回族自治区的青铜峡峡 谷出口处,为距离稳定性封冻河段最近的控制性水 库, 其出库流量是影响研究区域凌情的一个重要因 素。从图 2 中可以看出, 2008 年以来, 青铜峡站各 年凌汛期下泄流量过程较为一致: (1) 11 月中旬至 12 月中旬, 青铜峡水库下泄流量逐渐增大; (2)12月中 旬至2月中旬,下泄流量较前一阶段略微减小,过程 平稳; 3 2 月中旬至 3 月中旬,下泄流量逐渐减小。 青铜峡水库自 2008 年以来各年凌汛期下泄流量过 程符合当前已经总结出的青铜峡水库理想下泄过 程 $^{[6]}$, 对于减小凌灾的发生几率具有重要的作用。 


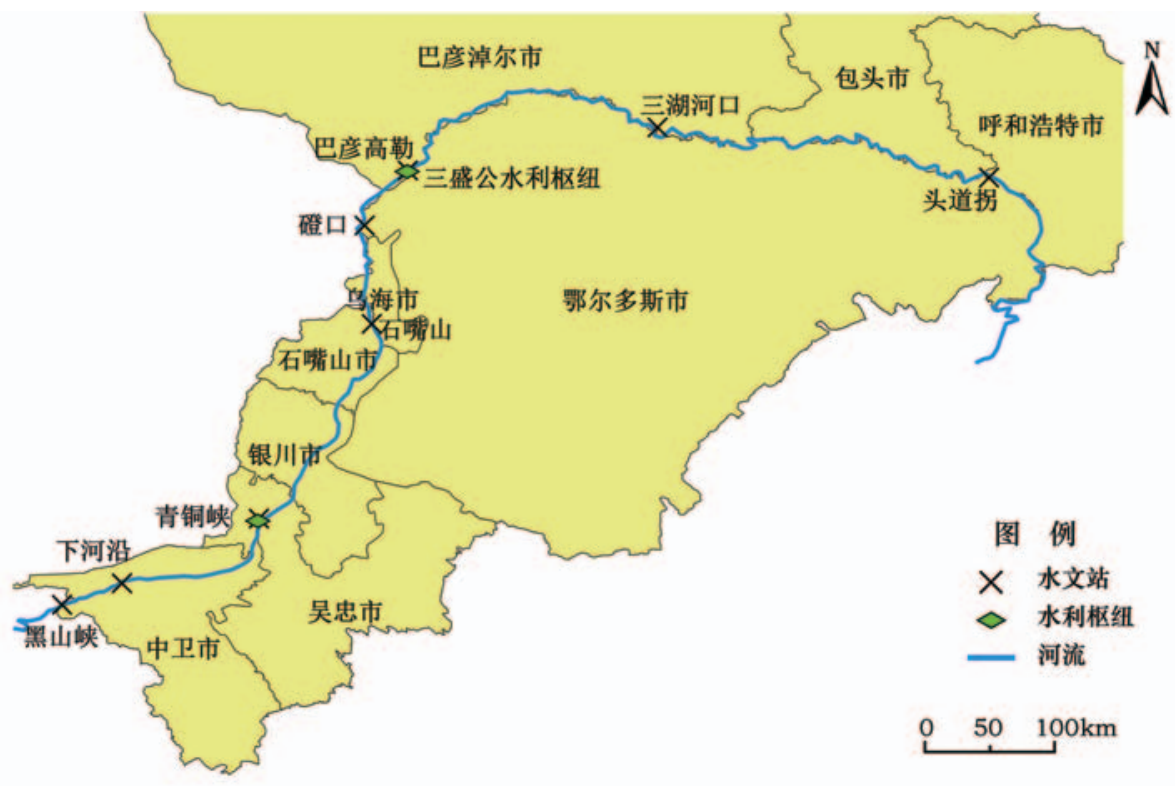

图 1 黄河宁蒙河段区位

Figure 1 Location of Ningxia-Inner Mongolia Reach of the Yellow River

青铜峡水库凌汛期下泄径流量如图 3 所示。自 1951 年以来,研究区域的来水量呈现逐渐增大的趋 势, 其中刘家峡水库投人运行前(1951-1968 年)凌 汛期平均径流量为 58.78 亿 $\mathrm{m}^{3}$, 自刘家峡水库运行 至龙羊峡水库运行期间(1969-1986年)凌汗期平均 径流量为 66.47 亿 $\mathrm{m}^{3}$, 较前一时期增大了 $13 \%$, 龙刘

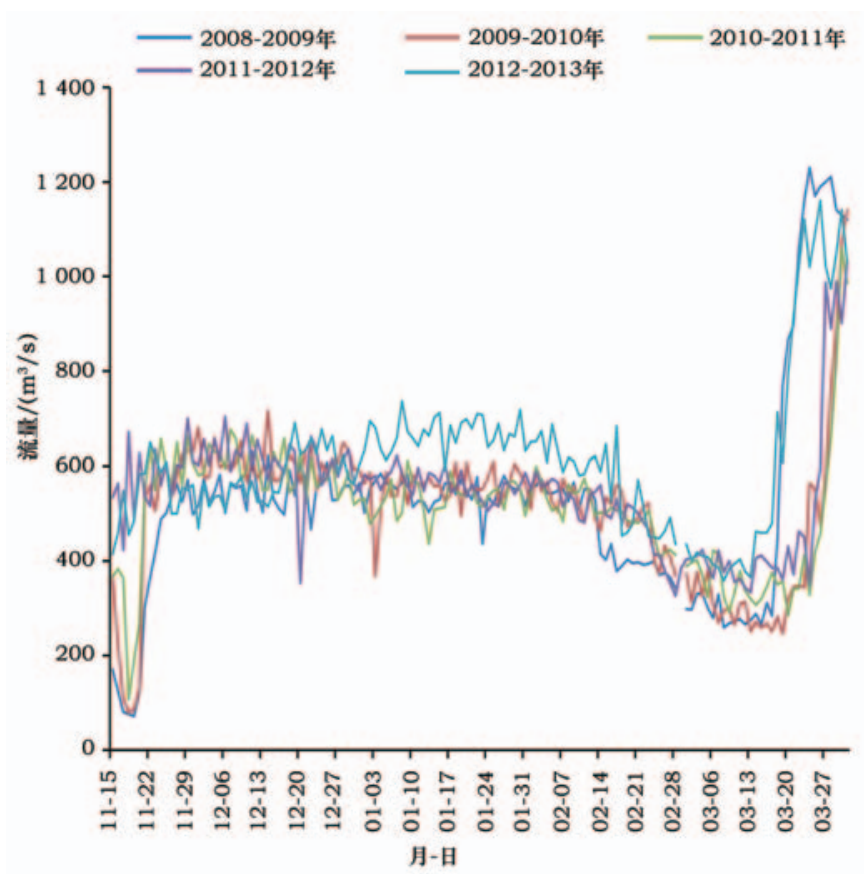

图 2 青铜峡水库凌汛期下泄流量过程

Figure 2 Discharge progress of Qingtongxia Reservoir during ice flood
水库联合运行后的 2008-2012 年间, 凌汛期平均径 流量为 71.22 亿 $\mathrm{m}^{3}$, 较刘家峡水库运行前增大了 $21.16 \%$ 。因此, 2008 年以来, 青铜峡水库凌汛期下 泄流量有所增大,但下泄过程基本不变。

\subsection{2 凌汛期水温变化过程}

图 4 为 1971-2012 年青铜峡站凌汛期平均水温 变化过程, 可以看出, 龙刘水库联合运行之前, 水温 较为稳定, 该时期凌汛期平均水温为 $2.82^{\circ} \mathrm{C}$ 。龙羊 峡水库投人运行后平均水温为 $3.68^{\circ} \mathrm{C}$, 比龙羊峡水 库运行前的平均水温增大 $0.86^{\circ} \mathrm{C}$,增幅为 $30.64 \%$ 。

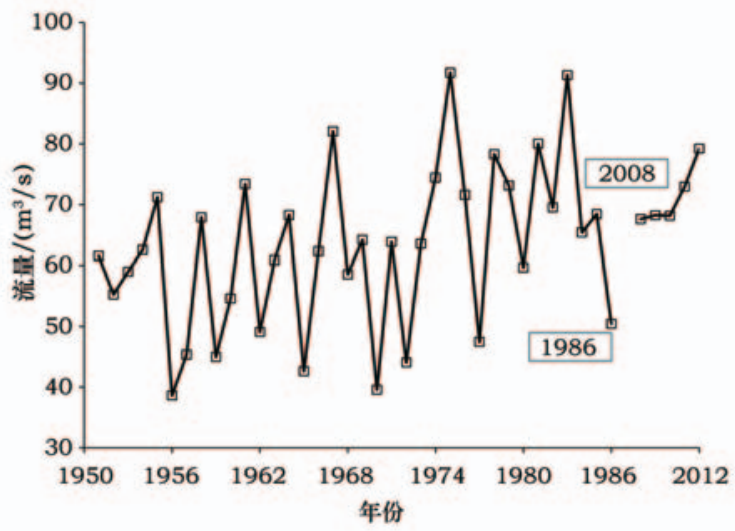

图 3 1951-2012 年青铜峡站凌汛期径流量变化过程

Figure 3 Variation of runoff at Qingtongxia Station during ice flood season from 1951 to 2012 


\section{2 凌汛前河道过水断面形态}

根据石嘴山、磴口、巴彦高勒、三湖河口、头道 拐 5 个水文站 2008-2013 年凌汛前的实测断面资 料,选取各站 6 次实测断面的最低水位作为各站的 同水位,计算该水位下的断面面积和平均水深,其 结果见表 1 。

\subsection{1 河道过水断面面积}

图 5 为研究区域 5 个水文站近年来凌汛前断面 面积变化曲线。2008-2013 年,石嘴山站凌汛前断 面面积除 2012 年较 2011 年有所减小外,其余各年 呈增加趋势; 磴口站 2010 年断面面积较 2009 年减 小, 其余各年呈增加趋势; 巴彦高勒站凌汛前断面 面积在 2008 年、 2010 年、2013 年较小, 在 2009 年、 2011 年、2012 年大幅增大,整体呈现大幅波动的变 化趋势; 三湖河口站凌汛前断面面积在 2010 年、 2011 年有所减小,其余各年呈增大趋势; 头道拐站 除 2009 年汛前断面面积较 2008 年减小外,其余各

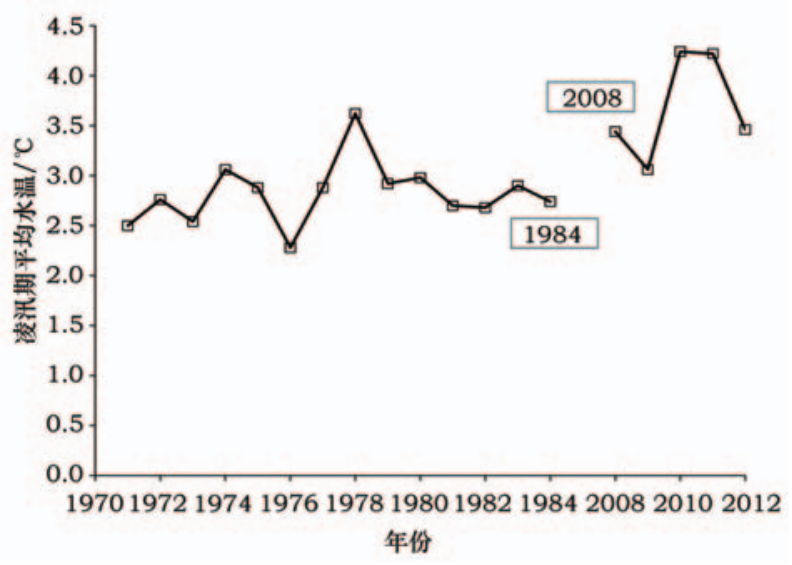

图 4 1971-2012 年青铜峡站凌汛期平均水温变化过程

Figure 4 Variation of mean water temperature at Qingtongxia Station during ice flood season from 1971 to 2012
年呈增大趋势。整体来看,石嘴山站、磴口站、三湖 河口站和头道拐站凌汛前断面面积近年来呈增大 趋势, 巴彦高勒站呈波动变化趋势。与 2008 年相 比,石嘴山、磴口、巴彦高勒、三湖河口、头道拐 5 个 水文站 2013 年汛前断面面积分别增大了 $80.90 \%$ 、 $58.78 \% 、 19.52 \% 、 78.08 \% 、 20.59 \%$,可以看出,研究区 域各站近年来凌汛前断面面积变化过程虽有所差 异,但最终均有所增大,其中石嘴山站、磴口站、三 湖河口站增幅较大,巴彦高勒站和头道拐站增幅 较小。

\subsection{2 河道平均水深}

图 6 为 2008-2012 年研究区域 5 个水文站近年 来凌汛前河道平均水深变化曲线。整体来看,各站 平均水深的年际变化趋势与断面面积较为一致,其 中石嘴山站、磴口站、三湖河口站和头道拐站凌汛 前平均水深呈增大趋势,巴彦高勒站呈波动变化趋 势。与 2008 年相比,石嘴山、磴口、巴彦高勒、三湖

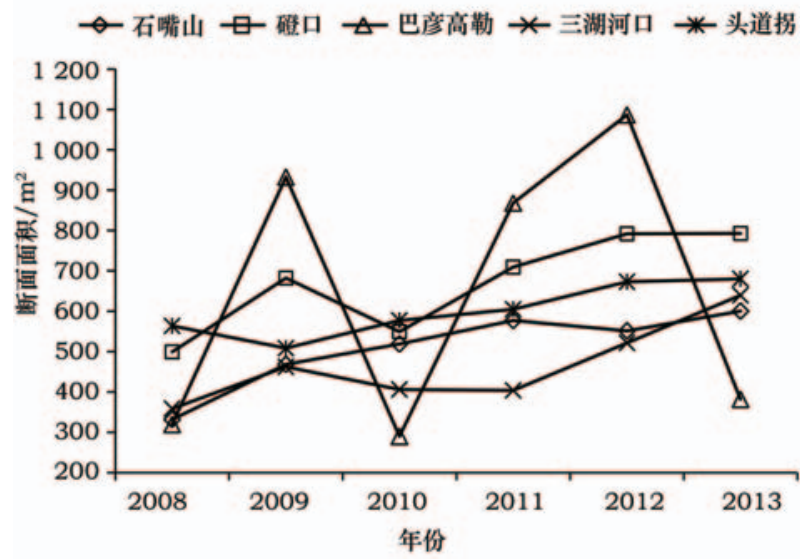

图 $52008-2013$ 年各水文站凌汛前断面面积

Figure 5 Cross-sectional area before ice flood season at main gauging stations from 2008 to 2013

表 1 凌汛前给定水位下河道断面形态参数

Table 1 Channel cross-section parameters under a given water level before ice flood season

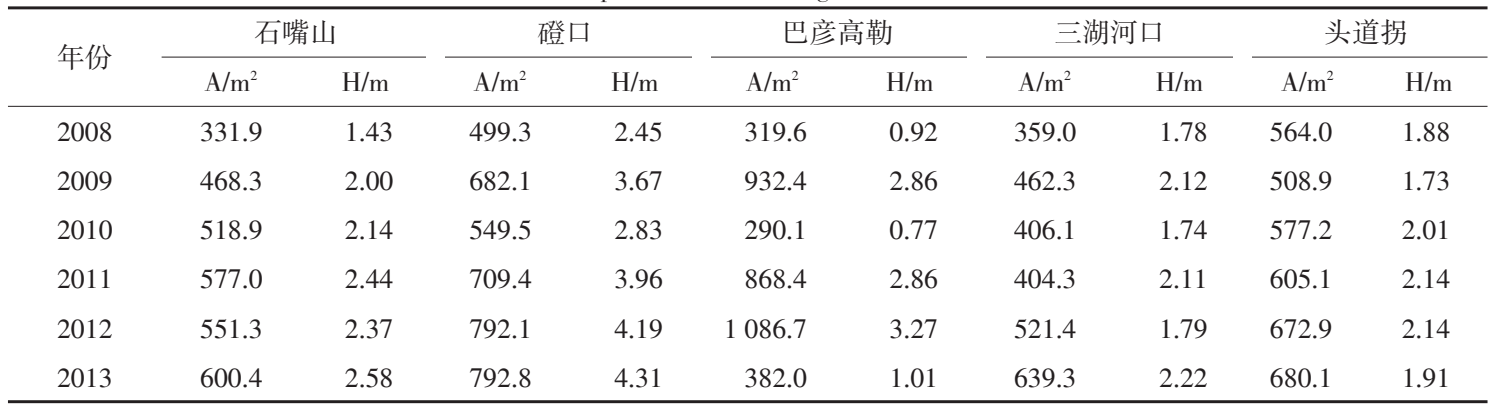

注: $\mathrm{A}$ 是同水位下的断面面积; $\mathrm{H}$ 是平均水深。 


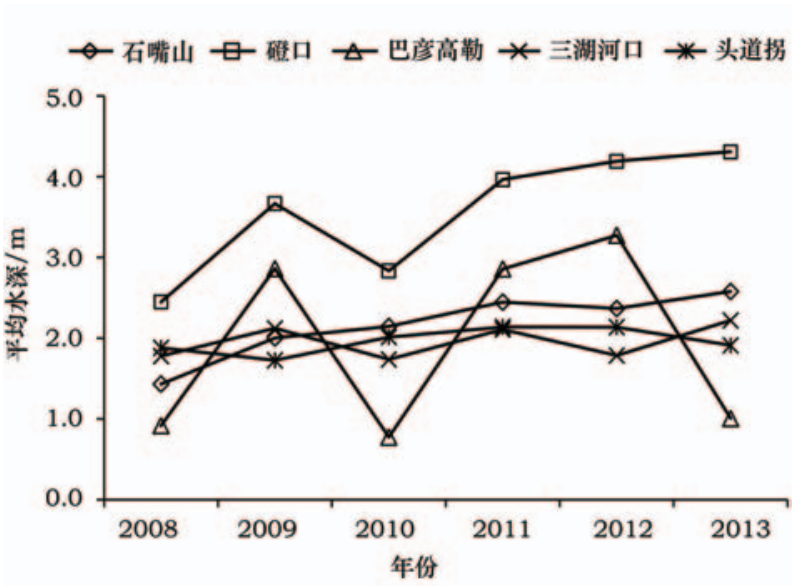

图 $62008-2013$ 年各水文站凌汛前平均水深

Figure 6 Mean water depth before ice flood season at the main gauging stations from 2008 to 2013

河口、头道拐 5 个水文站 2013 年凌汛前平均水深分 别增大了 $80.12 \% 、 76.04 \% 、 9.77 \% 、 24.90 \% 、 1.62 \%$, 可以看出, 研究区域各站近年来凌汛前平均水深均 有所增大, 其中石嘴山站、磴口站、三湖河口站增幅 较大,巴彦高勒站和头道拐站增幅较小。

\subsection{3 河道深泓点高程}

根据 5 个水文站各年凌汛前的实测断面资料, 得到各测次的深泓点高程,各站深泓点高程年际变 化如图 7 所示。2008-2013 年, 石嘴山站 (图 7a)深 泓点高程逐渐降低, 至 2013 年, 深泓点高程降低了 $2.33 \mathrm{~m}$; 磴口站 (图 7b) 深泓点高程在 2010 年、2013 年抬升, 其余各年均降低, 5 年间深泓点高程降低了 $0.72 \mathrm{~m}$; 巴彦高勒站 (图 7c) 深泓点呈现抬升与下降 不断交替的波动变化趋势,其 2013 年高程较 2008 年降低了 $0.37 \mathrm{~m}$; 三湖河口站 (图 7d) 深泓点高程在 2013 年抬升,其余各年均不断降低, 5 年间深泓点高 程降低了 $1.05 \mathrm{~m}$; 头道拐站 (图 7e) 深泓点高程在 2008-2012 年呈降低趋势, 在 2013 年深泓点高程出 现了较大的抬升。整体来看,石嘴山、磴口、巴彦高 勒、三湖河口 4 个水文站凌汛前断面深泓点高程经 过 5 年的演变有所降低,其中石嘴山和三湖河口站 降低幅度相对较大。

\section{5 讨论与结论}

\section{1 讨论}

2008-2013 年间, 宁蒙河段凌汛特点表现为封 河日期推迟, 封冻时长缩短, 封冻期水下过流能力
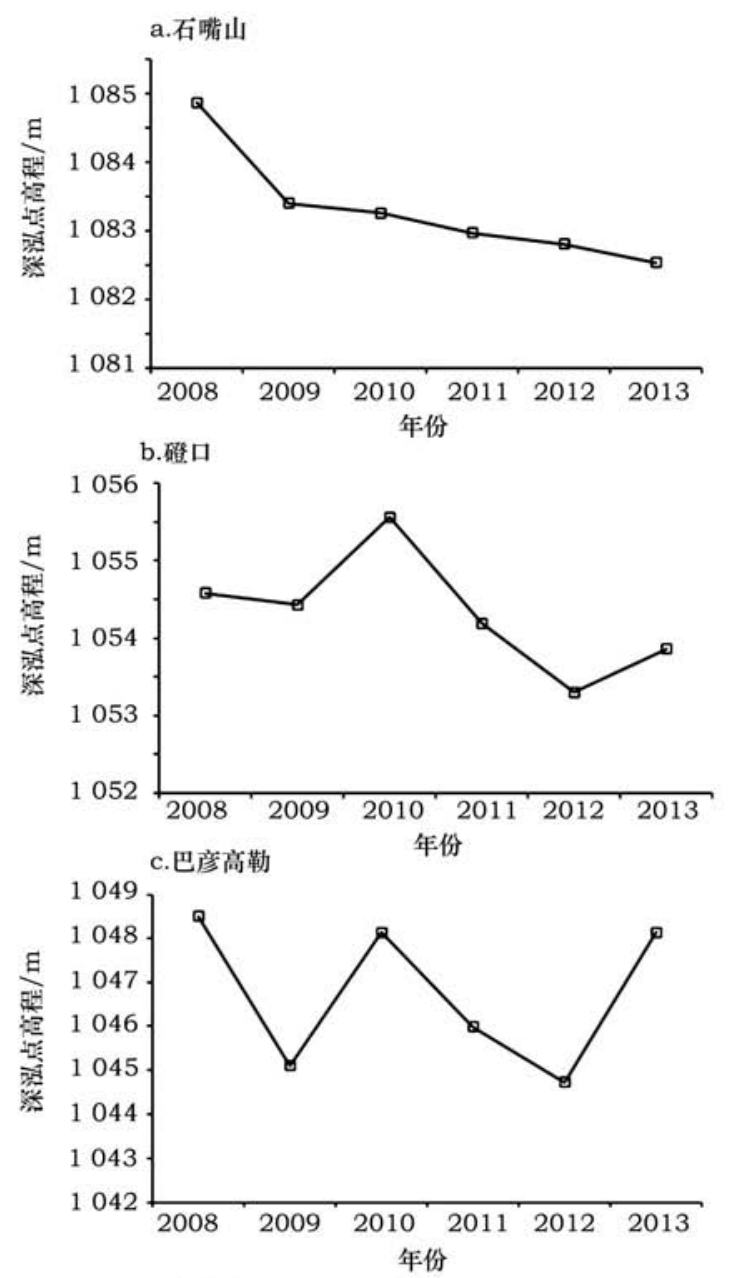

d.三湖河口
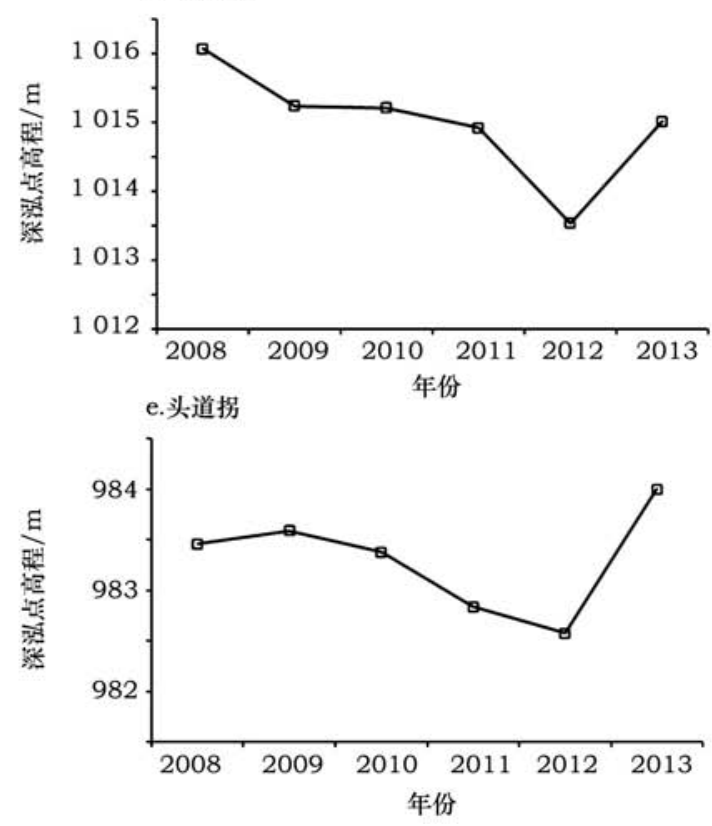

图 7 2008-2013 年各水文站凌汛前断面深泓点高程年际变化

Figure 7 Variation of thalweg's elevation before ice flood season from 2008 to 2013 
增强, 开河期水位较低, 凌峰流量偏小 ${ }^{[24-26]}$ 。20102011 年度凌汛期, 宁蒙河段首封时间较常年(19702005 年)偏晚 5 天,开河期水位偏低,其中三湖河口 站最高水位为 $1020.42 \mathrm{~m}$, 为 2004 年以来最低 ${ }^{[26]}$ 。 2012-2013 年凌汛期间大部分河段水位及同水位下 流量较近 10 年同期有所增大,封河期冰层厚度较

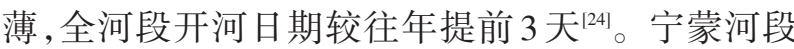
凌汛特点的如上变化与水文-水文过程、河道形态 等的变化关系密切。

青铜峡水库距离稳定封冻河段最近,通过调控 水文过程对石嘴山一头道拐河段的凌汛过程和变幅 产生影响。对青铜峡水库2008-2013 年凌汛期出库 流量的分析表明,一方面,在水库的调度下,各年凌 汛期的流量过程较为一致,符合理想下泄流量过 程,有利于减少可能出现的凌灾; 另一方面,宁蒙河 段凌汛期的来水量在 2008-2013 年间有所增大,这 对于减小封河期的河槽蓄水量、削减开河期的凌峰 流量十分有利, 同时能够更好的满足宁蒙灌区的冬 季引水。水库的运行对库下河水的水温也产生了 影响,2008-2013 年间凌汛期平均水温较龙刘水库 联合运行前升高了 $0.86^{\circ} \mathrm{C}$, 有助于缩减封冻时间,减 小冰层厚度。

“十大孔兑”是稳定封冻河段的主要支流,其夏 季汛期容易形成高含沙水流,在与干流交汇处形成 沙坝, 导致干流水位雍高, 流速降低, 泥沙在河道内 淤积 ${ }^{[27]}$ 。然而随着气候变化与流域水土保持措施的 开展，“十大孔兑”的径流量和输沙量均呈减小的趋 势 ${ }^{[28,29]}$ 。水沙条件的这种变化缓解了夏汛期支流人 汇处的淤堵,有利于河道在凌汛期有较好的过流 能力。

2008-2013 年间,稳定封冻河段的河道形态发 生了变化。分析结果表明,稳定封冻河段 5 个水文 站凌汛前的断面面积和平均水深近年来均呈逐渐 增大的趋势, 除头道拐站外的 4 个水文站的深泓点 高程也有所降低。河道形态的这些变化表明凌汛 期河道的过水面积在逐渐增大, 这有助于增大河道 的过流能力, 减小槽蓄水量, 对缓解宁蒙河段的凌 汛灾情能够产生有利影响。

此外,巴彦高勒站凌汛前河道断面形态参数近 年来呈现波动变化,变化幅度较大, 这与该河段的
稳定性有关。该站位于辫状河段, 水动力相对较 强, 河岸组成物质的抗冲性差, 河道最不稳定 ${ }^{[23]}$, 这 对于凌汛灾害的防治不利。

\section{2 结论}

通过对宁蒙河段稳定封冻区域近年来水文过 程和河道形态的分析,本研究详细分析了宁蒙河段 水文-水文和河道形态的变化特征,并揭示了这些 变化对凌汛的影响。得到了如下主要结论:

（1）2008-2013 年间,宁蒙河段凌汛期径流量增 大, 水温升高, 青铜峡水库下泄流量过程符合理想 流量下泄过程曲线,有助于减少凌汛灾害的发生。

(2)各主要水文站凌汛前的断面面积和平均水 深等断面形态参数呈逐年增大的趋势, 深泓点高程 也不断降低, 增大了凌汛期河道的过流能力, 有助 于缓解开河期可能出现的凌汛灾情。

2008 年以来, 宁蒙河段凌汛期水文过程及河道 形态变化有利于减少凌汛灾情的发生,但巴彦高勒 站所在河段仍需加强监测与防治, 从而应对可能出 现的凌汛灾情。

\section{参考文献(References)：}

[1] Beltaos S. River ice jams: Theory, case studies, and applications [J]. Journal of Hydraulic Engineering, 1983, 109 (10) : 13381359.

[2]王富强,魏怀斌. 基于小波变换的宁蒙河段凌情多尺度分析 [J]. 干旱区资源与环境, 2014,28(11) : 83-89. [Wang F Q, Wei H B. Multi-time scale analysis of ice regime in Ningxia-Inner Mongolia reach based on wavelet transform[J]. Journal of Arid Land Resources and Environment, 2014,28(11):83-89.]

[3] 那济海,周秀杰,许秀红,等. 黑龙江、松花江和嫩江冰坝凌汛 发生原因及预报方法[J]. 自然灾害学报,2011,20(2)：115120. [Na J H, Zhou X J, Xu X H, et al. Cause and forecast of ice jam and run in Heilong River, Songhua River and Nenjiang River [J]. Journal of Natural Disasters ,2011,20(2) : 115-120.]

[4]鲁仕宝,黄强,吴成国,等. 黄河宁蒙段冰凌灾害及水库防凌措 施[J]. 自然灾害学报, 2010,19(4) : 43-47. [Lu S B, Huang Q, Wu C G, et al. Ice jams disaster in Ningxia- Inner Mongolia reaches of the Yellow River and its prevention by reservoirs[J]. Journal of Natural Disasters, 2010,19(4):43-47.]

[5]赵炜. 历史上的黄河凌汛灾害及原因[J]. 中国水利, 2007, (3): 43-46. [Zhao W. Ice jam disasters in the Chinese history and reasons[J]. China Water Resources, 2007, (3) :43-46.]

[6] 陈广圣,王义民,黄强,等. 青铜峡水库出库流量对宁蒙河段凌 
情的影响[J]. 自然灾害学报, 2013,22(5): 198-203. [Chen G S, Wang Y M, Huang Q, et al. Influence of discharge of Qingtongxia Reservoir on ice run in Ningxia- Inner Mongolia reaches[J]. Journal of Natural Disasters, 2013,22(5):198-203.]

[7] 冀鸿兰. 黄河内蒙段凌汛成因分析及封开河日期预报模型研 究 [D]. 呼和浩特: 内蒙古农业大学, 2002. [Ji H L. Factor Analysis for Ice Flood and Model Research for Freeze-Up Time and Breakup Time in the Inner Mongolia Reach of the Yellow River[D]. Hohhot: Inner Mongolia Agricultural University ,2002.]

[8] 王文东,张芳华,康志明,等. 黄河宁蒙河段凌汛特征及成因分 析[J]. 气象, 2006,32 (3) : 32-38. [Wang W D, Zhang F H, Kang $\mathrm{Z} \mathrm{M}$, et al. Characteristics and causes of ice flood in NingxiaInner Mongolia section of the Yellow River valley[J]. Meteorological Monthly, 2006,32(3) :32-38.]

[9]王富强,王雷. 近 10 年黄河宁蒙河段凌情特征分析[J]. 南水北 调与水利科技, 2014, 12 (4) : 21-24. [Wang F Q, Wang L. Analysis of ice regime characteristics in the Ningxia- Inner Mongolia reach of Yellow River in the recent ten years[J]. Southto-North Water Transfers and Water Science \& Technology, 2014, 12(4):21-24.]

[10] 姚惠明, 秦福兴, 沈国昌, 等. 黄河宁蒙河段凌情特性研究[J]. 水科学进展, 2007, 18(6):893-899. [Yao H M, Qin F X, Shen G $\mathrm{C}$, et al. Ice regime characteristics in the Ningxia-Inner Mongolia reach of Yellow River[J]. Advances in Water Science, 2007,18(6): 893-899.]

[11] 蔡琳, 卢杜田,蔡彬. 水库调节对江河防凌的作用 [J]. 冰川冻 土, 2002, 24 (2) : 206-208. [Cai L, Lu D T, Cai B. Regulating function of reservoirs on ice jam flood control[J]. Journal of Glaciology and Geocryology, 2002,24(2):206-208.]

[12] 黄强,李群,张泽中,等. 龙刘两库联合运用对宁蒙河段冰塞影 响分析[J]. 水力发电学报,2008,27(6):142-147. [Huang Q, Li Q, Zhang Z Z, et al. Impact of ice jam by Long- Liu reservoirs joint operation in the Ningxia-Inner Mongolia reach[J]. Journal of Hydroelectric Engineering ,2008,27(6) : 142-147.]

[13] 刘晓岩,司源. 黄河上游水库调节对宁蒙河段防凌的影响 [J]. 人民黄河, 2011,33(10) : 4-6. [Liu X Y, Si Y. Effect of reservoir operation in the upper Yellow River on ice prevention in NingxiaInner Mongolia reach[J]. Yellow River, 2011,33(10) : 4-6.]

[14] 胡春宏,张治吴. 黄河口尾问河道横断面形态调整及其与水沙 过程的响应关系 [J]. 应用基础与工程科学学报, 2011,19(4): 543-553. [Hu C H, Zhang Z H. Relationship between adjustment of section configuration and flow-sediment of tail channels in the Yellow River estuary[J]. Journal of Basic Science and Engineering, 2011, 19(4) :543-553.]

[15] 胡春宏,陈建国,刘大滨,等. 水沙变异条件下黄河下游河道横 断面形态特征研究[J]. 水利学报, 2006,37 (11) : 1283-1289. [Hu C H, Chen J G, Liu D B, et al. Studies on the features of cross section's profile in the lower Yellow River under the conditions of variable incoming water and sediment[J]. Journal of Hydraulic Engineering , 2006,37(11):1283-1289.]

[16] 龙虎,杜宇,邬虹霞,等. 黄河宁蒙河段河道淤积萎缩及其对凌 汛的影响[J]. 人民黄河, 2007,29(3): 25-26. [Long H, Du Y, Wu H X, et al. Shrink and its impact on the ice floods in the Ningxia-Inner Mongolia reach of Yellow River[J]. Yellow River, $2007,29(3): 25-26$.]

[17] 刘吉峰,杨健,霍世青,等. 黄河宁蒙河段冰凌变化新特点分析 [J]. 人民黄河, 2012 ,34 (11) : 12-14. [Liu J F, Yang J, Huo S Q， et al. Analysis on some new ice characteristics in Ningxia-Inner Mongolia reach of the Yellow River[J]. Yellow River, 2012, 34 (11) : 12-14.]

[18] 李秋艳,蔡强国,方海燕. 黄河宁蒙河段河道演变过程及其影 响因素研究[J]. 干旱区资源与环境, 2012,26(2) : 68-73. [Li Q Y, Cai Q G, Fang H Y. Channel evolvement and influence factors in Ningxia-Inner Mongolia reach of the Yellow River [J]. Journal of Arid Land Resources and Environment ,2012,26(2):68-73.]

[19] 许畑心. 黄河内蒙古段支流“十大孔兑”侵蚀产沙的时空变化 及其原因[J]. 中国沙漠, 2014,34 (6) : 1-9. [Xu J X. Temporal and spatial variations in erosion and sediment yield and the cause in the ten small tributaries to the Inner Mongolia reach of the Yellow Ricer[J]. Journal of Desert Research, 2014,34(6): 1-9.]

[20] 吴保生. 内蒙古十大孔兑对黄河干流水沙及冲淤的影响[J]. 人 民黄河, 2014,36(10):5-8. [Wu B S. Effect of the ten major tributaries in the Inner Mongolia on the runoff and sediment load as well as sedimentation in the main stream of the Yellow River [J]. Yellow River, 2014,36 (10):5-8.]

[21] 冯国华, 朝伦巴根, 间新光. 黄河内蒙古段冰凌形成机理及凌 汛成因分析研究[J]. 水文, 2008,28(3): 74-76. [Feng G H, Chaolun B G, Yan X G. Analysis of ice slush formation mechanism and ice flood causes of Yellow River in Inner Mongolia [J]. Journal of Hydrology, 2008, 28 (3) : 74-76.]

[22] 黄河水利委员会. 黄河流域水文资料(第2册)[M].郑州: 黄河水 利委员会, 2008-2013. [Yellow River Conservancy Commission. Hydrometric Data in the Yellow River Basin (Vols.2) [M]. Zhengzhou: Yellow River Conservancy Commission ,2008-2013.]

[23] Su T, Wang S J, Mei Y G, et al. Comparison of channel geometry changes in Inner Mongolian reach of the Yellow River before and after joint operation of large upstream reservoirs[J]. Journal of Geographical Sciences,2015,25(8):930-942.

[24] 毛利强, 张一兵, 吴迷芳. 黄河宁蒙段 2012-2013 年度凌情特 点分析[J]. 黄河水利职业技术学院学报,2014,(2):9-11. [Mao L Q, Zhang Y B, Wu M F. Ice-run situation feature analysis on Yellow River Ningxia-Inner Mongolia section from 2012-2013[J]. Journal of Yellow River Conservancy Technical Institute, 2014, (2) : $9-11$.

[25] 陈冬伶,王兵,范曼昊. 黄河宁蒙河段 2009-2010 年度凌情特 点分析[J]. 人民黄河, 2012,34(1):22-24. [Chen D L, Wang B, 
Fan M H. Characteristics of ice condition in Ningxia- Inner Mongolia reach of the Yellow River from 2009 to 2010[J]. Yellow River ,2012,34(1):22-24.]

[26] 张丙夺,张兴红,尚冠华. 2010-2011 年度黄河凌情特点与防 凌措施[J]. 人民黄河, 2011,33(12):6-8. [Zhang B D, Zhang X $\mathrm{H}$, Shang G H. Ice regime characteristic and ice flood protection measures of the Yellow River in 2010-2011[J]. Yellow River. 2011,33(12):6-8.]

[27] 张原锋,王平,侯素珍,等. 黄河上游干支流交汇区沙坝淤堵形 成条件[J]. 水科学进展, 2013,24(3):333-339. [Zhang Y F, Wang P, Hou S Z, et al. On conditions of sandbar clogging at confluences in the upper Yellow River[J]. Advances in Water
Science, 2013,24(3):333-339.]

[28] 郭彦,侯素珍,林秀芝. 近 51 年西柳沟流域水沙变化特征分析 [J]. 干旱区资源与环境, 2014,28(10): 176-183. [Guo Y,Hou S Z, Lin X Z. Variation characteristics of runoff and sediment in Xiliugou River basin for recent 51 years[J]. Journal of Arid Land Resources and Environment, 2014,28(10) : 176-183.]

[29] 刘通,黄河清,邵明安,等. 气候变化与人类活动对鄂尔多斯地 区西柳沟流域人黄水沙过程的影响[J]. 水土保持学报, 2015, 29 (2) : 17-22. [Liu T, Huang H Q, Shao M A, et al. Impacts of climate change and human activity on process of water and sediment load along Yellow River in Erdos[J]. Journal of Soil and Water Conservation, 2015,29(2):17-22.]

\title{
Effect of hydrological processes, water temperature and river channel geometry changes on ice floods in the Ningxia-Inner Mongolia Reach of the Yellow River
}

\author{
SU Teng ${ }^{1,2}$, HUANG Heqing ${ }^{1}$, ZHOU Yuanyuan ${ }^{1}$ \\ (1. Key Laboratory of Water Cycle and Related Land Surface Processes, Institute of Geographic Sciences and Natural Resources Research, \\ Chinese Academy of Sciences, Beijing 100101, China; \\ 2. University of Chinese Academy of Sciences, Beijing 100049, China)
}

\begin{abstract}
The hydrological process and water temperature process have changed markedly during the flood season in the Ningxia- Inner Mongolia reach of the Yellow River in recent decades. Assessing the impact on river channel geometry, ice floods and the possible disaster- causing effects are needed Based on cross- sectional data measured before each ice flood season at Shizuishan, Dengkou, Bayangaole, Sanhuhekou and Toudaoguai gauging stations located in the stable frozen section of the Ningxia-Inner Mongolia reach from 2008 to 2013, we selected the lowest water level for each station as the given water level to calculate geometrical parameters under a given water level. To reveal geometrical changes in cross section effectively, we selected channel cross-section area, mean water depth and elevation of thalweg in order to analyze changes. We found that runoff and mean water temperature during each flood season increased from 2008 to 2013 in the Ningxia- Inner Mongolia reach of the Yellow River. The discharge process of the Qingtongxia Reservoir in each ice flood season accorded with ideal discharge processes and thus contributed to a reduction in ice flood disasters. The cross- section area and mean water depth before each ice flood season showed an increasing trend year by year at the five main gauging stations, while the elevation of thalweg dropped comparatively. These changes in channel geometry caused the enhancement of flow capacity, helpful for relieving possible disasters during thawing periods.
\end{abstract}

Key words : Ningxia-Inner Mongolia Reach; ice flood; channel's geometry ; hydrological process; water temperature process 